\title{
Analysis on Demand for International Business Talents in Provinces in the Central China
}

\author{
Yiqun Wu \\ Hunan International Business Vocational College, Changsha, 410201, China
}

\begin{abstract}
Keywords: International business; higher vocational colleges; provinces in central China; demand for talents
\end{abstract}

\begin{abstract}
To know the demand for international business talents in provinces in central China, 150 foreign trade enterprises in provinces in central China are investigated and analyzed, and the results show that the international business skilled talents with document clerk and salesman as the core are badly needed in the foreign trade enterprises and the enterprises pay more attention to the employees' communication capacity, practical operation capacity, occupational qualities and foreign language proficience in the selection of foreign trade staff. Considering this circumstance, it is required to define the cultivation objective of international business talents in higher vocational colleges, continuously perfect the curriculum system, highlight the cultivation of students' capacity and strengthen the university-enterprise cooperation, thus providing high-quality talents resource for the development of foreign trade industry in provinces in central China.
\end{abstract}

\section{Introduction}

The international trade is the main cultivation direction of international trade major in higher vocational colleges and the cultivation of international business talents aims at serving the foreign trade industry in provinces in Central China and knowing the demand for international business talents in provinces in central China, so as to promote the relevant curriculum reform in higher vocational colleges and the setting of the cultivation plan of international trade talents. From the above, it can be seen that the research is of important realistic significance.

I. Description of research

(I) Research objective

With the further development of reform and opening up, the China's trade process has developed greatly. Provinces in central China, such as Hubei, Shanxi, Anhui, Hunan, Jiangxi and Henan, are of the fastest development of foreign trade and their trade growth is higher than national foreign trade growth and national economic growth. The demand for international business talents in provinces in central China is studied, the demand for talents of foreign trade enterprises in provinces in central China is mastered and the enterprises' opinions on curriculum of international business major in higher vocational colleges are known, thus providing references to the reform of teaching method and content and the compilation of talents cultivation objective.

(II) Research content

The investigation content mainly includes three parts: 1) conduct statistics of name, establishment date, scope of business, nature, specific address, scale, number of employees, contact, contact information, employee reward and other basic information of foreign trade enterprise; 2) master the current staff structure of unit to be investigated, job hunt problems of college graduate, unit's evaluation of graduate, badly needed position of unit, factors highlighted by unit upon recruitment, educational requirements of talents needed, way of talents recruitment, qualification and work experience of talents needed, and demand for talents in the next few years; 3) foreign trade enterprises' opinions on curriculum of international business major in higher vocational colleges, know the skills needed by international business talents, practicability of curriculum of business major, importance of language curriculum for business talents and importance of second foreign language curriculum based on the actual situation of foreign trade, and analyze whether the corresponding foreign trade knowledge training and professional skill training are set to strengthen the ability of international business talents. 


\section{Analysis of investigation results}

(I) Analysis of investigation results of demand for talents

\section{Overall demand for talents}

The investigation results show that the foreign trade enterprises in provinces in central China have a great demand for international business talents. Among the 157 investigated foreign trade enterprises, 5 trade talents are needed averagely, that is, about 450,000 international trade talents are needed by 90,000 foreign trade enterprises in provinces in central China. However, the annual average graduates of higher vocational colleges in provinces in central China are 2,000,000 students, among which the number of graduates of international business major is less than 150,000 students. Considering the employment of graduates at different levels and inflow of talents outside the province, the demand for international business talents in provinces in central China can provide a sufficient development space for the development of students in higher vocational colleges.

2. Position needed by foreign trade enterprises

SME is the main form of foreign trade enterprises in provinces in central China and the declarant, document clerk, foreign trade salesman, inspection staff, foreign trade merchandiser, commercial secretary, foreign trade assistant and freight forwarding businessman are inclusive in foreign trade positions, in which the business assistant, foreign trade merchandiser and foreign trade salesman are position badly needed by foreign trade enterprises and the inspection staff and commercial secretary are the positions with the least demand.

(II) Requirements of foreign trade enterprises on skills of practitioner

1. Requirements on professional ability of practitioner

The foreign trade enterprises pay more attention to the business negotiation, order receiving, documentary, communication and English listening, speaking, reading and writing ability of employees and the employees are required to continuously improve their market research and development ability, continuously enrich their trade knowledge in work. The enterprises pay less attention to the management, financial, legal and other ability of employees.

2. Factors highlighted by enterprises

The foreign trade enterprises pay great attention to the communication, practical ability, working attitude and foreign language ability of practitioners. It can be found from the actual investigation that in addition to the above factors, the enterprises also consider the learning and innovation ability, educational background and professional knowledge of job seekers. Among the respondents, about half enterprises think the professional knowledge is important, about $30 \%$ of enterprises think the learning and innovation ability and educational background are important, and about $10 \%$ of enterprise have requirements on age, product knowledge, computer competence and place of domicile of practitioners. The research shows that strengthening the students' communication, practical and foreign language ability as well as comprehensive occupational qualities plays an important role in cultivating international trade talents.

3. Requirements on relevant certificate

The occupational qualification of staff is most concerned in the recruitment of foreign trade enterprises. At present, to make students meet the requirements of job position, the international business major in higher vocational colleges actively encourage students to conduct corresponding training, so as to have an in-depth understanding of international business industry and position requirements. Among the international trade related certificates, the certificate of document clerk, certificate of merchandiser and certificate of declarant are the main requirements of foreign trade enterprises on practitioners and then the enterprises will consider the e-commerce certificate, accountant's practice qualification certificate and certificate of inspection staff as well as certificate of international freight forwarding according to their actual situation. The document clerk and merchandiser are the main development direction of foreign trade business major, in which the merchandiser is the start of departmental manager and businessman. With the continuous development of foreign trade industry and expansion of foreign trade field, the position of merchandiser in foreign trade industry continuously rises, with broad development prospect and the greatest demand in foreign trade enterprises, from which the importance of certificate of foreign 
trade merchandiser is clear.

(III) Analysis of curriculum setting of international business major

1. Requirements on foreign trade skills and product knowledge

The main trade sectors in provinces in central China mainly include furniture manufacturing, metal products, textile, garment and electronic products. To make students better meet the requirements of position, fastly adapt to the job and smoothly and pass the transition period from school to enterprise, some enterprises think it is required to strengthen students' professional skills and relevant training of product knowledge and other enterprises think the systematic product introduction can expand students' knowledge, but also make students form a fixed thinking model, so as to affect their future development.

\section{Analysis of language course}

The employees' English interpretation and spoken English abilities are also concerned by foreign trade enterprises. Therefore, it is required to pay more attention to students' simultaneous interpretation or spoken English level in the professional curriculum, reasonably increase the weight of spoken English and English interpretation and reduce the weight of English reading. Besides, the learning of German, Japanese, language of African countries and other second foreign language is very necessary.

3. Role of professional curriculum in practical foreign trade

From the perspective of foreign trade enterprises, among the courses of international business major in higher vocational colleges, the Foreign Trade English Correspondence and International Trade Practice are most effective and other courses, such as Customs Declaration Practice, Foreign Trade Document Practice, Business Negotiation, Marketing and Foreign Trade Merchandiser Practice can also enhance students' foreign knowledge to a certain degree. International Trade Practice, with the strongest practicability of international business major, is the fundamental course and plays an important role in improving students' international trade ability. However, in the actual teaching of some higher vocational colleges, the teaching content and method are somewhat out-dated and the teaching mode cannot conform to the development of times because the teaching material and teacher-based teaching in the classroom is only formal and cannot strengthen students' professional skills. Therefore, the curriculum reform of international business major is necessary.

\section{Enlightenment and suggestions on the cultivation mode of international business talents}

There is a big gap between the talents required by foreign trade industry and the cultivation of international business talents in higher vocational colleges, so it is allowed to better meet the enterprises' requirements and conform to the development of times only through the reform of talents cultivation mode. The goal can be realized by the following measures:

(I) Define the cultivation objective of professional talents

In addition to combining the features of the educational development of international business major in higher vocational colleges, it is required to aim at guiding students' employment and serving the society in the setting of talents cultivation objective. Combining the current situation of international trade in central and east China, the international business major should define the talents cultivation objective and build a team of all-around talents with high comprehensive quality, strong responsibility, professional skills and knowledge about foreign trade merchandiser, document and export sales, so as to provide sufficient human resources for the development of foreign trade enterprises in provinces in central China and promote the development and progress of their foreign trade economy.

(II) Emphasize the cultivation of students' soft capacity

In addition to the high requirements on the professional skills of employees, the foreign trade enterprises also pay great attention to their professional morality because only the one who can treat the work carefully and has high psychological quality and strong responsibility can do a work well. Therefore, in the cultivation of international business talents, the teacher is required to conduct reasonable adjustment of the teaching content and teaching method according to the specific requirements of international trade positions, excavate students' potential to the greatest extend in 
the form of teamwork and strengthen the cultivation of students' soft capacity. Meanwhile, it is required to enhance the building of students' view of employment and values and make students enter the society through professional occupational training and substituted post exercitation, so as to make them feel the responsibility in the practical international trade work and form good professional ethics and hardworking and persistent work style.

(III) Perfect the curriculum system

Unlike other industry, the international trade industry pays more attention to the professional skills and practical operation ability of practitioners, in which most positions have certain requirements on the employees' occupational qualifications. Thus, it is required to set the curriculum according to the features of international trade to form a perfect and reasonable curriculum system. In the construction of curriculum system, the responsibilities, job content and requirements of different positions of international trade major should be analyzed and the occupational qualification certification, such as foreign trade declarant, document clerk and merchandiser should be enhanced in the curriculum system. It can be realized from the following aspects: combine the course of Customs Declaration Practice with the declarant's qualification test, combine the courses of International Business Document Practice and International Trade Practice with the document clerk's qualification test, and combine the course of Foreign Trade Merchandise Practice and International Trade Practice with the merchandiser's qualification test. It should be noted that the corresponding occupational standard and requirements should be introduced under the actual work task and real work environment with the typical works of position as the main direction based on the occupational features of international trade business, so as to optimize the curriculum system.

(IV) Strengthen the university-enterprise cooperation

The education objective of higher vocational colleges is the employment and service orientation and the principle that must be obeyed in the educational reform is the industry-university-research cooperation. However, some higher vocational colleges lack of understanding of university-enterprise cooperation, leading to ideal employment of students. Therefore, the international business major in higher vocational colleges should pay more attention to the exchange, communication and cooperation with foreign trade enterprises to timely master the changes of actual requirements of job position, and conduct professional training of students by recruiting the staff of foreign trade enterprises to make students set clear learning goals and promote the optimization of relevant curriculum system and development of teaching materials. In addition, it is required to make full use of university-enterprise cooperation to ensure students' off-campus training and substituted post exercitation, improve the students' practicing quality, deepen the understanding between students and foreign trade enterprises and make students meet the demand of international trade industry for talents.

\section{References}

[1] Hu Fangrong. Analysis on Countermeasures of Foreign Trade Development in Central China[D]. Northeast University of Finance, 2011.

[2] Yang Ligao, Zhou Jianhua, Liu Jianjiang. Research on Market-Oriented Cultivation Mode of Applied International Trade Talents[J]. China Electric Power Education, 2012(29).

[3] Yuan Xiangdong, Chen Dongmei, Yang Hongmei. Research on Foreign Trade Problems in Central China under the Perspective of New Economic Geography[D]. Hunan University of Science and Technology, 2010.

[4] Wan Jinhong, Wang Liwen, Li Xia, Hu Jie. Research on Cultivation of Applied Talents of International Trade Practice Major in Higher Vocational Colleges[J]. Science and Technology Innovation Herald, 2011(03).

[5] Zheng Hefen. Research on Demand for International Trade Talents in Higher Vocational Colleges[J]. Journal of Henan Institute of Science and Technology (Vocational Education Edition), 2012(03).

[6] Wei Jieyu. Construction and Implementation of Vocational Ability Cultivation-Oriented 
Curriculum System[J]. Logistics Engineering and Management, 2011(10).

[7] Wang Haibo, Liu Zhihong. Exploration on Construction of Curriculum System in Higher Vocational Colleges Based on Position Analysis[J]. Vocational \& Technical Education Forum, 2012(04).

[8] Huang Yun. Reform of Employment-Oriented Cultivation Mode of International Economic and Trade Talents in Higher Vocational Colleges[J]. Literary Education (2), 2012(08).

[9] Wang Shuyun, Liu Xuewen. Innovation of Social Demand-Oriented International Trade Talents Cultivation[J]. China Adult Education, 2011(13).

[10] Deng Zhixin, Wan Shoufu, Zhang Lijun. Exploration on Training Base Construction Mode of University and Enterprise[J]. China Electric Power Education, 2013(32). 